\title{
Local and regional impact of anthropogenic drainage on fen contiguity
}

\author{
A. H. van $\operatorname{Loon}^{1}$, P. P. Schot ${ }^{1}$, M. F. P. Bierkens ${ }^{2,3}$, J. Griffioen ${ }^{3}$, and M. J. Wassen ${ }^{1}$ \\ ${ }^{1}$ Department of Environmental Sciences, Copernicus Institute, Utrecht University, P.O. Box 80115, Utrecht 3508 TC, \\ The Netherlands \\ ${ }^{2}$ Department of Physical Geography, Utrecht University, Utrecht, The Netherlands \\ ${ }^{3}$ TNO Geological Survey of The Netherlands, Utrecht, The Netherlands
}

Received: 28 April 2009 - Published in Hydrol. Earth Syst. Sci. Discuss.: 17 June 2009

Revised: 01 September 2009 - Accepted: 10 September 2009 - Published: 12 October 2009

\begin{abstract}
Knowledge of the hydrological mechanisms behind habitat fragmentation of fen plant communities in intensively managed regions like The Netherlands is essential to improve currently utilized fen restoration and conservation strategies. In this study, we analysed the local and regional impact of anthropogenic drainage on the groundwater supply of fens. For this purpose, we developed finescale groundwater flow models and collected empirical data to analyse (1) the differences in groundwater supply between an anthropogenically drained fen and a poorly drained fen in The Netherlands, and (2) the local and regional effects of the elimination of drainage ditches on the groundwater supply of fens. Our results consistently indicated the presence of recently infiltrated precipitation on top of upwelling groundwater across the anthropogenically drained fen, and a mixing gradient of recently infiltrated precipitation and upwelling groundwater across the poorly drained fen. Furthermore, our results showed that the elimination of drainage ditches from the anthropogenically drained fen increased the area and the flux of groundwater supply of both the anthropogenically drained fen and the poorly drained fen. We conclude that anthropogenic drainage not only causes a lowering of groundwater tables, but also (1) enhances the infiltration of local precipitation across fens while simultaneously preventing upwelling groundwater from entering the fen root zone, and (2) reduces the groundwater supply of adjacent fens by intercepting groundwater that is potentially directed to downstream regions. These insights support the need to reconsider the current priorities in hydrological fen restoration strategies.
\end{abstract}

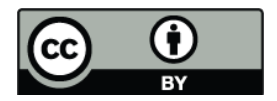

Correspondence to: P. P. Schot (p.schot@geo.uu.nl)

\section{Introduction}

Although the sustainable conservation and restoration of endangered plant species in Europe has been internationally agreed upon since the early 1990s (Council of Europe, 2000), only modest progress has been made to counteract the negative effects of land reclamation and environmental degradation on fens. One of the reasons is that currently utilized fen restoration strategies are often ineffective in counteracting habitat loss and fragmentation of the remaining fen plant populations (Klimkowska et al., 2007). Habitat fragmentation is disadvantageous for species if ecological barriers prevent seed dispersal or the genetic exchange between populations (Ozinga et al., 2009; Hooftman et al., 2003). For low-productive fens, these ecological barriers may consist of zones of ceased groundwater supply, as these zones are thought to be less suitable for the establishment and survival of most fen plant species (Sjörs and Gunnarsson, 2002). The hydrological mechanisms behind the development of zones of ceased groundwater supply are still poorly understood; however, this knowledge is essential to improve currently utilized fen restoration strategies. In this paper, we analyse how anthropogenic drainage affects the groundwater supply of fens.

Particularly ambitious efforts to conserve and restore lowproductive fens have been undertaken in The Netherlands, because these fens usually harbour a high diversity of plant species, many of which have a threatened status (Lamers et al., 2002). Low-productive fens are typical of sites with a low nutrient availability (Bedford et al., 1999) and a nearneutral pH (Sjörs and Gunnarsson, 2002). These site factors are usually conditioned by the supply of both upwelling groundwater and local precipitation (Amon et al., 2002). The excessive water supply causes shallow groundwater tables

Published by Copernicus Publications on behalf of the European Geosciences Union. 
and anaerobic conditions in the shallow subsurface (De Mars and Wassen, 1999; Boomer and Bedford, 2008b). In addition, dissolved minerals are transported by the groundwater to the fen surface. Both the shallow groundwater tables and the supply of dissolved minerals maintain the acidity of fens at a near-neutral pH level (Kemmers et al., 2003; Almendinger and Leete, 1998), and limit nutrient availability for plant growth provided the sulphate concentration of the groundwater is low (Boomer and Bedford, 2008a; Lamers et al., 1998).

Environmental degradation of low-productive fens may consist of desiccation, acidification, or eutrophication (Lamers et al., 2002). These degradation processes are often triggered by a shift in the origin of groundwater supply as a result of water management practices. In particular, drainage (Schot et al., 2004) and groundwater abstractions (Fojt, 1994) are thought to prevent groundwater from entering the fen root zone, because they intercept groundwater that is potentially directed to the fen surface. This decreased supply of groundwater may cause a fall in groundwater tables and enhances the infiltration of local precipitation and surface water (Van Wirdum, 1991). As the chemical compositions of precipitation and surface water deviate from that of groundwater, an increase of these infiltration rates are thought to cause abiotic conditions that are less suitable for fen plants (Wassen et al., 1990; Fojt and Harding, 1995).

Since exfiltrating groundwater mediates abiotic conditions that are suitable for fen plants (Klijn and Witte, 1998), habitat loss and fragmentation of low-productive fens may be related to the development of zones of ceased groundwater supply, i.e., the disintegration of spatially contiguous zones of groundwater supply. Spatially contiguous zones of groundwater supply are common in natural fens, including those in Poland (Van Loon et al., 2009b), Germany (Succow and Joosten, 2001), and Siberia (Schipper et al., 2007). In managed fens, however, these zones have become dispersed as a result of regional changes in groundwater flow caused by anthropogenic developments (Van Loon et al., 2009a). Furthermore, it is hypothesized that the interception and subsequent discharge of groundwater by drainage ditches may further reduce the area, and thus the contiguity of zones of groundwater supply. This hypothesis is supported by 2-D groundwater flow and transport models (Schot et al., 2004) and hydrochemical field surveys at numerous drained fens (Grootjans et al., 1988; Wassen et al., 1990; Bootsma et al., 2002). These studies indicate that anthropogenically drained fens are not supplied with groundwater, but with locally infiltrated precipitation. None of the studies, however, provide a spatially explicit analysis of the impact of anthropogenic drainage on the groundwater supply of fens. This knowledge is essential for the improvement of the current perception of the hydrological mechanisms behind fen deterioration.

This paper presents an analysis of the impact that anthropogenic drainage has on the groundwater supply of fens. We not restricted ourselves to on-site, local effects, but we also analysed how changes in water management on a local scale affect downstream regions, i.e., exert effects on a regional scale. For this purpose, we developed fine-scale groundwater flow models and collected empirical data to analyse (1) the differences in groundwater supply between an anthropogenically drained fen and a poorly drained fen, and (2) the effects of the elimination of drainage ditches on the local and regional groundwater supply of fens. We hypothesize that anthropogenic drainage (1) directs local groundwater flow to the drainage ditches and thus prevents upwelling groundwater from entering the fen root zone (Schot et al., 2004), and (2) intercepts groundwater that is potentially directed toward downstream regions and thus reduces the groundwater supply of adjacent fens.

\section{Study area}

The Naardermeer is a polder in the centre of The Netherlands $\left(52^{\circ} 17^{\prime} \mathrm{N}\right.$ and $\left.5^{\circ} 8^{\prime} \mathrm{W}\right)$ that is comprised of fens, a number of lakes, and pastures (Fig. 1a). The Naardermeer is bordered to the east by the ice-pushed ridge Het Gooi. This ridge consists of elongated hills of sandy fluvial deposits that had been pushed up by glaciers during the Saalien glaciation. Owing to its relatively high topography $(0-30 \mathrm{~m}$ a.s.1.), the icepushed ridge functions as a regional groundwater recharge area (Schot, 1989). Land cover of the ridge consists of urban areas, heaths, and forests. Groundwater abstractions for drinking water production were removed from the ridge during the 1990s in order to enhance groundwater flow to the fens in the Naardermeer.

The Naardermeer is bordered to the north, south, and west by other polders (Fig. 1a). Polders are water management districts from which excessive water is drained by means of dense ditch networks and discharged by pumping. In periods of water deficit, however, the ditch networks are used to irrigate the polders with alien surface water that is pumped in to acquire optimal conditions for agricultural crop production. Owing to their low topography $(-1.7$ to $-1.1 \mathrm{~m}$ a.s.l.), these polders form the regional drainage basis of the Naardermeer, implying that infiltration conditions prevail at the downstream margins of the Naardermeer (Schot et al., 1988). Water losses caused by infiltration and evapotranspiration are compensated for by the supply of alien surface water to the north-western lake of the Naardermeer during the summer season (Barendregt et al., 1995).

The anthropogenically drained fen in the eastern part of the Naardermeer comprises a $500 \mathrm{~m}$ wide zone adjacent to the ice-pushed ridge Het Gooi (Fig. 1b). This fen is drained by parallel drainage ditches that are $0.4-1.0 \mathrm{~m}$ deep and spaced $30-60 \mathrm{~m}$ apart. These drainage ditches are relicts of the former agricultural use of this fen. The fen has now become an extensively managed buffer zone to protect the downstream fens and Lake Naardermeer from eutrophication (Barendregt et al., 1995). The surface water levels in 

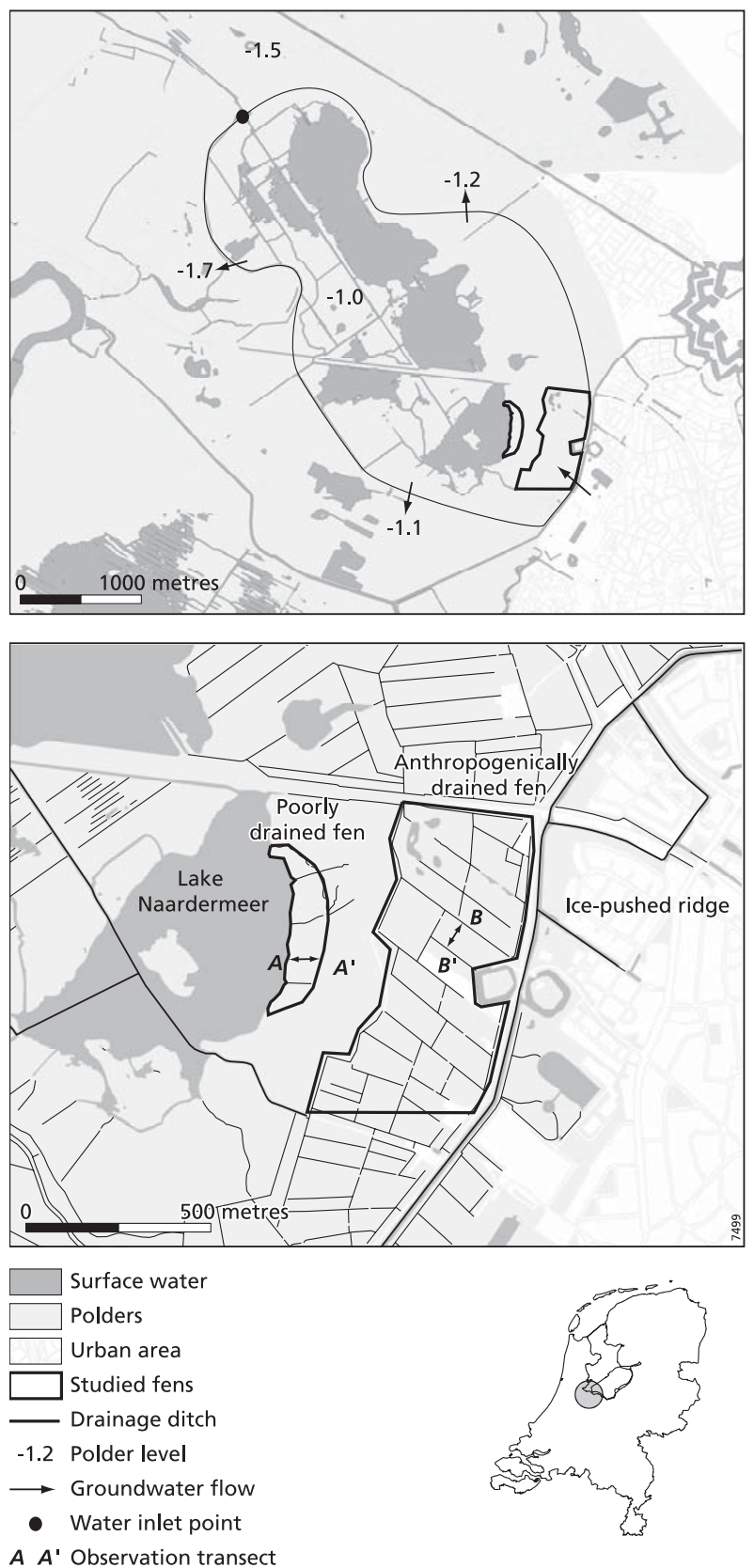

Fig. 1. Topographic maps of (a) the Naardermeer, The Netherlands, and (b) the anthropogenically drained fen and the poorly drained fen.

the drainage ditches are anthropogenically controlled at 0.4 $0.7 \mathrm{~m}$ below ground surface by means of weir constructions and a supply of alien surface water via the ditches during periods of water deficit in summer. Ground surface elevations of the anthropogenically drained fen range from -1.0 to $0.0 \mathrm{~m}$ a.s.l. As a result of this relatively low topography, groundwater flow is directed from the ice-pushed ridge to the fen (Schot, 1989).
The poorly drained fen is situated along one of the lakes in the Naardermeer (Fig. 1b). This fen is drained not only by the lake, but also by few shallow drainage ditches. The impact of these draining elements on groundwater flow through the fen is limited, however, as the fen is only slightly elevated above the lake level (Wassen et al., 1989). Alien surface water supplied to Lake Naardermeer does not reach the lake bordering the poorly drained fen. Owing to its low topography ( -1.0 to $-0.5 \mathrm{~m}$ a.s.1.), the poorly drained fen is supplied with both groundwater recharged at the ice-pushed ridge and brackish palaeo-groundwater (Wassen et al., 1989; Schot et al., 1988) that originates from early Holocene sea water intrusions (Post et al., 2003).

Groundwater flow to, and within, the Naardermeer is through aquifers consisting of unconsolidated, fluvial deposits. The hydrological base of the study area consists of early Pleistocene clays of marine origin at -250 to $-150 \mathrm{~m}$ a.s.l. Discontinuous resistance layers consisting of fluvial clays interfinger the aquifers laterally. The ice-pushed ridge consists of coarse sands that are partly intercalated with sloping clay sheets in the east. A semi-confining peat layer with a thickness up to 0.8 to $1.0 \mathrm{~m}$ is present in the Naardermeer. This peat layer is not present at the ice-pushed ridge.

\section{Method}

\subsection{Groundwater modelling}

Groundwater exfiltration patterns across both the anthropogenically drained fen and the poorly drained fen were established using a 3-D groundwater flow model. This groundwater flow model consisted of six model layers that were defined according to the geological stratigraphy of the catchment of the Naardermeer. The horizontal resolution of the model was 5 by $5 \mathrm{~m}$. This high horizontal resolution corresponds to the resolution of the most detailed digital elevation model available (Van Heerd et al., 2000) and serves to accurately establish groundwater exfiltration patterns on a local scale. The groundwater flow model was based on the MODFLOW code (McDonald and Harbaugh, 1988) and was developed in three successive stages. Initially, we developed a regional steady-state groundwater flow model of the catchment of the Naardermeer and its surroundings (for details of the model set-up see Van Loon et al., 2009a). The model grid size was 50 by $50 \mathrm{~m}$. Transmissivities were calibrated using time-averaged hydraulic heads observed in 659 monitoring wells between 2000 and 2005. Then, the steadystate groundwater flow model was modified into a transient groundwater flow model representative for 2006. Transient behaviour was determined by temporally varying groundwater recharge, groundwater abstractions and surface water levels. Transient equilibrium was accomplished by resuming the model run using the modelled heads at December 2006 as starting heads for January 2006, until stable starting heads 
were obtained. Finally, the transient groundwater flow model was refined at the Naardermeer through telescopic mesh refinement. The boundary fluxes of the local groundwater flow model were obtained from the regional groundwater flow model, however, no feedback was established between these models. Changes in water storage within the studied fens as a result of this missing feedback (Mehl et al., 2006) were prevented by (1) defining the model boundaries a few kilometres from the studied fens, and (2) accomplishing transient equilibrium for the refined model. Except for ground surface elevations, surface water levels, and drain conductivities, the resolution of the input data was the same for both the local and the regional groundwater flow models.

\subsection{Corroboration with empirical data}

The methods that are available to observe hydraulic heads were not sufficiently accurate to establish hydraulic head gradients on the small spatial scale of this study. Therefore, we corroborated the modelled groundwater exfiltration patterns using chemical and physical properties of water in order to identify patterns in source waters. The source waters considered in this study were (1) locally infiltrated precipitation, (2) upwelling fresh groundwater, (3) upwelling brackish palaeogroundwater, and (4) alien surface water. These source waters were identified using the indicators chloride $(\mathrm{Cl})$, electrical conductivity (EC), and tritium $\left({ }^{3} \mathrm{H}\right)$. Observed gradients in the $\mathrm{Cl}, \mathrm{EC}$, and ${ }^{3} \mathrm{H}$ concentrations were visualised with isolines that were established by Kriging interpolation using a linear variogram model.

Chloride was used as an indicator of alien surface water in the anthropogenically drained fen, because (1) the $\mathrm{Cl}$ concentration of alien surface water is usually relatively high compared to that in the other source waters (Table 1), and (2) $\mathrm{Cl}$ behaves conservatively during flow, i.e., $\mathrm{Cl}$ is not involved in any chemical or biological process that may alter its concentration in the groundwater during flow. Based on the ion concentrations of the source waters (Table 1), we used $\mathrm{Cl}$ concentrations exceeding $20 \mathrm{mg} / \mathrm{l}$ as indicators of alien surface water.

Chloride was used as an indicator of upwelling brackish palaeo-groundwater for the poorly drained fen: concentrations exceeding $300 \mathrm{mg} / \mathrm{l}$ were used as indicators of brackish palaeo-groundwater, concentrations below $20 \mathrm{mg} / \mathrm{l}$ as indicators of the absence of brackish palaeo-groundwater, and concentrations between $20 \mathrm{mg} / \mathrm{l}$ and $300 \mathrm{mg} / \mathrm{l}$ as indicators of mixtures of brackish palaeo-groundwater and source waters that contained low amounts of $\mathrm{Cl}$ (Table 1).

The indicator we used to establish patterns of locally infiltrated precipitation was EC, because (1) the EC of precipitation clearly deviates from the EC of the fens' other source waters (Table 1), and (2) compared to individual ion concentrations, the EC is less sensitive to the hydrochemical evolution of infiltrated precipitation that may acquire a groundwater signature during flow. We used ECs below $200 \mu \mathrm{S} / \mathrm{cm}$ as
Table 1. Chloride, EC, and tritium in the water sources of the Naardermeer.

\begin{tabular}{llll}
\hline & $\mathrm{Cl}[\mathrm{mg} / \mathrm{l}]$ & $\mathrm{EC}[\mu \mathrm{S} / \mathrm{cm}]$ & ${ }^{3} \mathrm{H}[\mathrm{TU}]$ \\
\hline Precipitation & $<10^{\mathrm{a}}$ & $<50^{\mathrm{a}}$ & $>11 \mathrm{TU}^{\mathrm{b}}$ \\
Alien surface water & $>100^{\mathrm{c}}$ & $590^{\mathrm{c}}$ & $45^{\mathrm{b}, 1}$ \\
Upwelling fresh groundwater & $<20^{\mathrm{c}}$ & $240^{\mathrm{c}}$ & $0^{\mathrm{d}}$ \\
Upwelling brackish groundwater & $>300^{\mathrm{c}}$ & & $0^{\mathrm{d}}$ \\
\hline
\end{tabular}

a RIVM, 2005, ${ }^{\mathrm{b}}$ Knetsch, 2007, ${ }^{\mathrm{c}}$ Schot and Wassen, 1993, ${ }^{\mathrm{d}}$ Robertson and Cherry, 1989. ${ }^{1}$ average concentration in surface water observed at Lobith (East Netherlands) and Maassluis (West Netherlands) in 2006. Note that ${ }^{3} \mathrm{H}$ in surface water at these locations ranged between 26 and 81 TU during 2006 and between 15 and 161 TU during 2005.

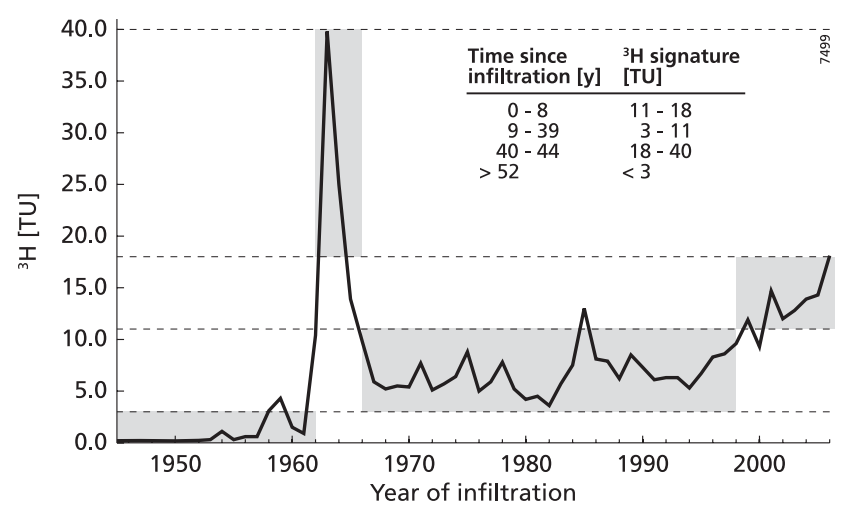

Fig. 2. Calculated ${ }^{3} \mathrm{H}$ concentration in groundwater for 2006 as a function of the year of infiltration by considering first-order decay of ${ }^{3} \mathrm{H}$. Tritium signatures of groundwater are indicted by the gray bars and they are listed above the graph.

indicators of locally infiltrated precipitation. Electrical conductivities exceeding $200 \mu \mathrm{S} / \mathrm{cm}$ are not ambiguous for any of the source waters as high ECs may relate to the presence of (1) chemically evolved, locally infiltrated precipitation, (2) upwelling groundwater, or (3) infiltrated alien surface water.

In order to identify patterns of locally infiltrated precipitation and upwelling fresh or brackish groundwater, ${ }^{3} \mathrm{H}$ was used as an indicator of groundwater-residence time. We defined ${ }^{3} \mathrm{H}$ signatures of groundwater by considering ${ }^{3} \mathrm{H}$ concentrations in groundwater at the sampling date as a function of the year of infiltration (see Fig. 2). These concentrations were calculated from time series of ${ }^{3} \mathrm{H}$ in precipitation in The Netherlands (compiled from Meinardi, 1994 and Knetsch, 2002,2007 ) and by considering first-order decay of ${ }^{3} \mathrm{H}$. Note that ${ }^{3} \mathrm{H}$ signatures established by this approach may underestimate groundwater residence times in the presence of alien surface water as a high ${ }^{3} \mathrm{H}$ load in alien surface water caused by industrial activities in the Rhine catchment (Table 1) can mask the presence in pre-modern groundwater, which is poor in ${ }^{3} \mathrm{H}$.

Chloride, EC, and ${ }^{3} \mathrm{H}$ concentrations of groundwater and surface water were determined across both the 
Table 2. Effects of the elimination of drainage ditches on the groundwater supply of the anthropogenically drained fen and the poorly drained fen: relative area of groundwater exfiltration and exfiltration flux outside the draining elements. Arrows are directed from the lowest to the highest value of corresponding areas or fluxes.

\begin{tabular}{|c|c|c|c|c|c|c|c|c|c|c|c|c|c|}
\hline & \multirow{3}{*}{$\begin{array}{l}\text { Precipitation } \\
\text { surplus }[\mathrm{mm} / \mathrm{d}]\end{array}$} & \multicolumn{6}{|c|}{ Relative area of groundwater exfiltration [\%] } & \multicolumn{6}{|c|}{ Total exfiltration flux $\left[\mathrm{m}^{3} / \mathrm{d}\right]$} \\
\hline & & \multicolumn{3}{|c|}{ Anthropogenically drained } & \multicolumn{3}{|c|}{ Poorly drained } & \multicolumn{3}{|c|}{ Anthropogenically drained } & \multicolumn{3}{|c|}{ Poorly drained } \\
\hline & & $\begin{array}{l}\text { Current } \\
\text { conditions }\end{array}$ & & $\begin{array}{l}\text { Ditches } \\
\text { eliminated }\end{array}$ & $\begin{array}{l}\text { Current } \\
\text { conditions }\end{array}$ & & $\begin{array}{l}\text { Ditches } \\
\text { eliminated }\end{array}$ & $\begin{array}{l}\text { Current } \\
\text { conditions }\end{array}$ & & $\begin{array}{l}\text { Ditches } \\
\text { eliminated }\end{array}$ & $\begin{array}{l}\text { Current } \\
\text { conditions }\end{array}$ & & $\begin{array}{l}\text { Ditches } \\
\text { eliminated }\end{array}$ \\
\hline February & 1.71 & 1.0 & $\rightarrow$ & 3.8 & 46.1 & $\rightarrow$ & 63.4 & 19 & $\rightarrow$ & 541 & 73 & $\rightarrow$ & 160 \\
\hline May & 0.22 & $11.3^{\mathrm{a}}$ & $\leftarrow$ & 2.6 & 63.1 & $\rightarrow$ & 77.4 & 18 & $\rightarrow$ & 191 & 40 & $\rightarrow$ & 77 \\
\hline July & -3.64 & 100.0 & $\leftrightarrow$ & 100.0 & 100.0 & $\leftrightarrow$ & 100.0 & 715 & $\rightarrow$ & 918 & 104 & $\rightarrow$ & 115 \\
\hline November & 2.67 & 0.4 & $\rightarrow$ & 4.4 & 42.6 & $\rightarrow$ & 59.8 & 23 & $\rightarrow$ & 684 & 79 & $\rightarrow$ & 171 \\
\hline
\end{tabular}

a Temporal increase of the area of groundwater exfiltration, as a result of the attenuation of local head gradients within the anthropogenically drained fen by the raised surface water levels on 1 May (see Fig. 3).

anthropogenically drained fen and the poorly drained fen. Samples were collected from observation wells at depths ranging from 0.25 to $2.0 \mathrm{~m}$ below the ground surface. The observation wells were installed in clusters of 2 or 4 and positioned along transects parallel to the expected direction of groundwater flow. The distance between observation clusters was at most $10 \mathrm{~m}$. A total of 42 observation wells was installed for this study, 20 at the anthropogenically drained fen and 22 at the poorly drained fen. The observation wells consisted of polyethylene tubes with a screen length of $5 \mathrm{~cm}$ and a diameter of $1.6 \mathrm{~cm}$. This small diameter was used to minimise the amount of extracted groundwater needed to obtain a representative groundwater sample, i.e., to minimi interference of the hydrochemical patterns across the fens that can be caused by sampling.

Samples were analysed for $\mathrm{Cl}$ in November 2005, April 2006, May 2006, August 2006, and November 2006. They were filtered using $0.45 \mu \mathrm{m}$ filters, stored in polyethylene bottles at $4^{\circ} \mathrm{C}$, and analysed within three days after sampling using ion chromatography in conformity with the instructions of the Laboratory of Geosciences (Utrecht University, The Netherlands). Electrical conductivities were measured using a field electrode every 4-6 weeks from November 2005 to April 2007 directly after sampling. In November 2006, 12 samples from both the anthropogenically drained fen and the poorly drained fen (total $=24$ ) were analysed for ${ }^{3} \mathrm{H}$. The samples were conserved in glass bottles according to the instructions of the Centre of Isotope Research (University of Groningen, The Netherlands). The samples were then artificially enriched by distillation and electrolysis to obtain the lowest detection limit of 0.2 tritium units $\left(1 \mathrm{TU}=1{ }^{3} \mathrm{H}\right.$ atom per $10^{18} \mathrm{H}$ atoms).

\subsection{Numerical experiment}

The local and regional effects of anthropogenic drainage on the groundwater supply of fens were analysed with a numerical experiment consisting of the elimination of drainage ditches from the anthropogenically drained fen. Local effects of anthropogenic drainage were defined as changes in groundwater level, exfiltration pattern and water balance of the anthropogenically drained fen. Regional effects of anthropogenic drainage were defined as changes in groundwater level, exfiltration pattern, and water balance of the poorly drained fen.

\section{Results}

\subsection{Anthropogenically drained fen}

The groundwater flow model indicates permanent groundwater exfiltration into the drainage ditches in the anthropogenically drained fen due to the maintenance of low surface water levels throughout the year (Fig. 3a). Outside the drainage ditches, however, groundwater only exfiltrates into the fen root zone when plant transpiration causes falling water tables during the periods of precipitation deficit (i.e., evapotranspiration exceeds precipitation, see Fig. 3b). During periods of precipitation surplus (i.e., precipitation exceeds evapotranspiration), groundwater infiltrates into the deeper soil due to the redistribution of excessive water by groundwater flow. As a result of this temporally varying groundwater exfiltration, the relative area of groundwater exfiltration outside the drainage ditches can yield 100\% during dry summer months, whereas it is less than 5\% during wet winter months (Table 2). Despite a slight precipitation surplus in May 2006, the modelled area of groundwater supply for this month is relatively large compared to those for the other months of precipitation surplus. This is caused by groundwater exfiltration into narrow zones parallel to the drainage ditches (Fig. 3b) due to the temporary attenuation of local head gradients by the anthropogenically raised surface water levels on 1 May 2006.

The modelled temporally varying groundwater exfiltration outside the drainage ditches is confirmed by the ECs 

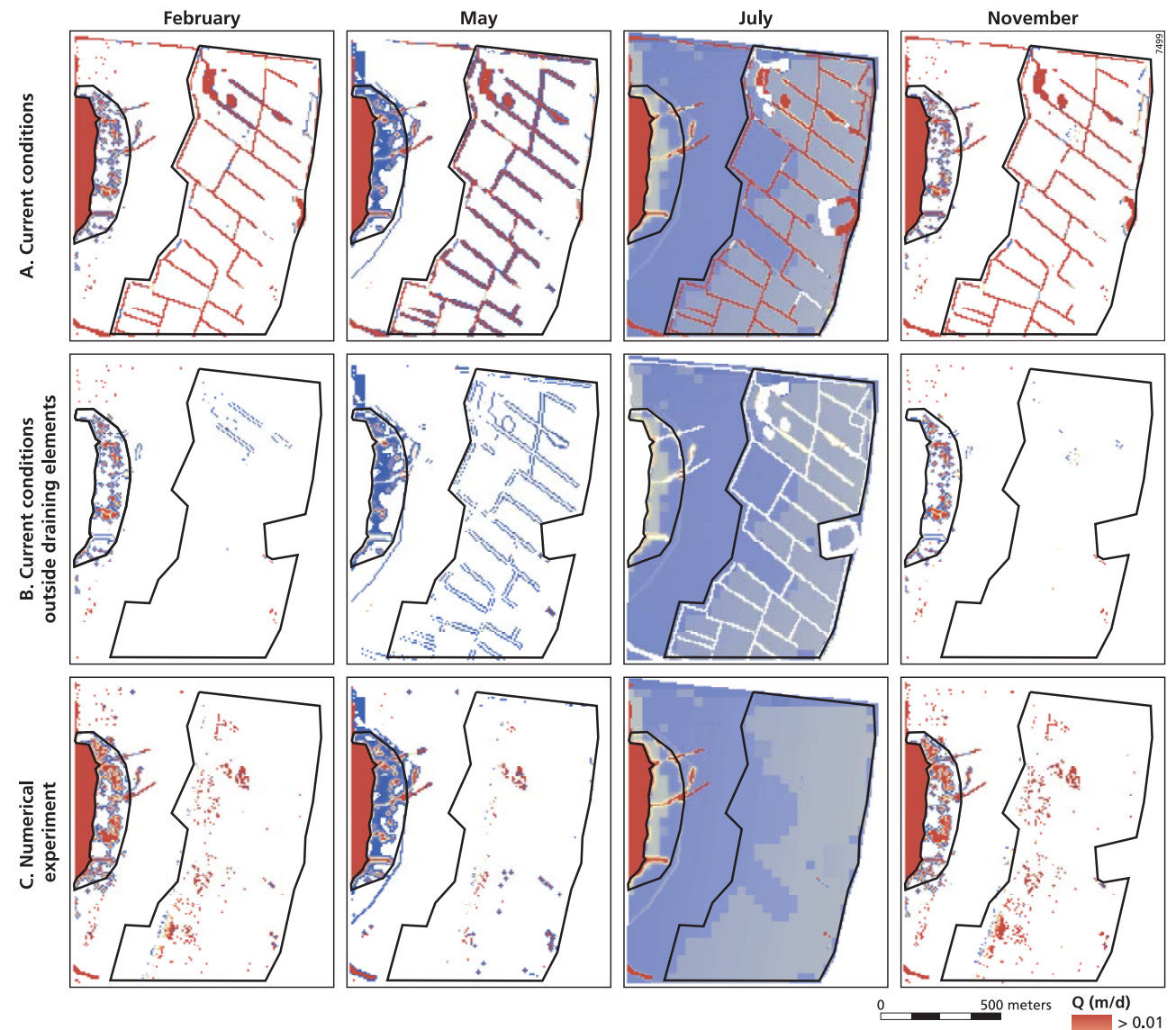

Fig. 3. Groundwater exfiltration fluxes (Q, m/d) across the Naardermeer modelled for February, May, July, and November 2006. (a) Current conditions for the entire fen area (b) Current conditions outside the drainage elements, (c) Numerical experiment consisting of the elimination of drainage ditches from the anthropogenically drained fen. Note that groundwater infiltration fluxes are not plotted in this figure in order to highlight differences and changes in groundwater exfiltration patterns.

observed across the anthropogenically drained fen (Fig. 4). The low ECs $(<200 \mu \mathrm{S} / \mathrm{cm})$ at the centre of the fen indicate the presence of a permanent rainwater lens of at least $1 \mathrm{~m}$ in depth. This rainwater lens expands in a vertical direction when there is a net infiltration of local precipitation during periods of precipitation surplus, and shrinks when locally infiltrated precipitation evaporates during periods of precipitation deficit. The shrinking of the rainwater lens is accompanied by a lowering of the groundwater table and by a shift from groundwater infiltration to exfiltration. This shift is indicated by the increased ECs at the centre of the fen from May 2006 to July 2006. Because of the permanently low Cl concentration in the groundwater $(\mathrm{Cl}<20 \mathrm{mg} / \mathrm{l}$, see Fig. 5), these increased ECs result from upwelling fresh groundwater, and not from the redistribution of infiltrated surface water from the ditches.

The observed ${ }^{3} \mathrm{H}$ concentrations provide further evidence of the presence of locally infiltrated precipitation $\left({ }^{3} \mathrm{H}>11 \mathrm{TU}\right)$ on top of older groundwater $\left(3 \mathrm{TU}<{ }^{3} \mathrm{H}<11 \mathrm{TU}\right)$ in the anthropogenically drained fen (Fig. 6). The observed ${ }^{3} \mathrm{H}$ pattern strongly resembles that of the EC, and confirms the presence of a rainwater lens of at least $1 \mathrm{~m}$ in depth. The relatively low ${ }^{3} \mathrm{H}$ concentrations (indicating infiltration before 1999 AD) in the groundwater under the drainage ditches confirm the modelled exfiltration into the drainage ditches; however, no pre-modern groundwater (infiltrated before 1962 AD) signified by ${ }^{3} \mathrm{H}$ concentrations below $3 \mathrm{TU}$ was found in the anthropogenically drained fen. As the $\mathrm{Cl}$ concentration near the drainage ditches permanently exceeded $20 \mathrm{mg} / \mathrm{l}$ (Fig. 5), the presence of pre-modern groundwater might have been masked by ${ }^{3} \mathrm{H}$ enrichment of the groundwater by the infiltrated alien surface water (Table 1).

\subsection{Poorly drained fen}

The groundwater flow model indicates permanent groundwater exfiltration into the topographic depressions near the 

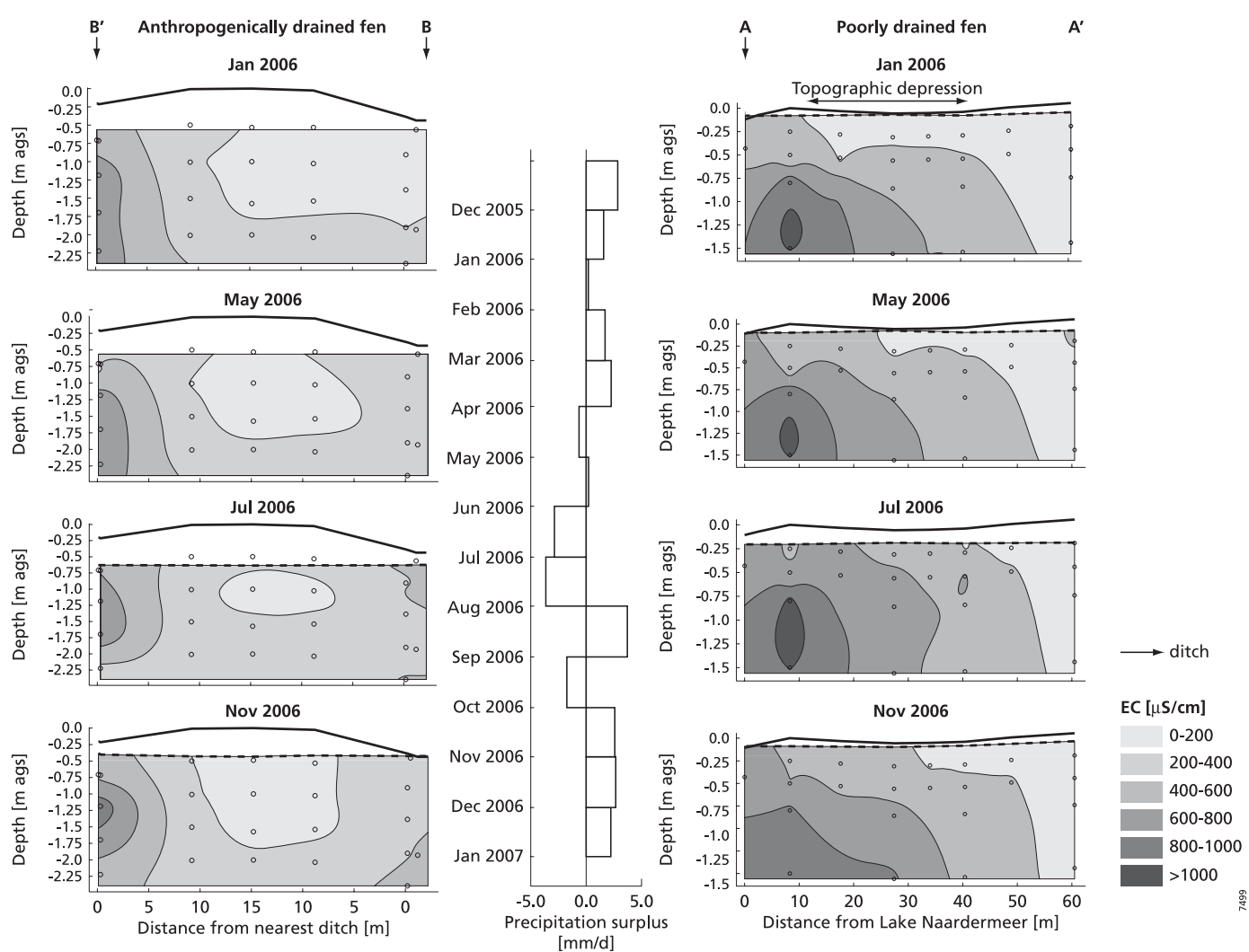

Fig. 4. ECs $[\mu \mathrm{S} / \mathrm{cm}]$ observed across the anthropogenically drained fen and the poorly drained fen in January, May, July, and November 2006. A-A $\mathrm{A}^{\prime}$ and $\mathrm{B}-\mathrm{B}^{\prime}$ signify the positions of the observation transects in Fig. 1 . Low ECs $(<200 \mu \mathrm{S} / \mathrm{cm})$ indicate the presence of locally infiltrated precipitation. The high ECs across the poorly drained fen correspond to a mixing gradient of brackish palaeo-groundwater and locally infiltrated precipitation.

centre of the poorly drained fen (Fig. 3a and b). This relates to the relatively low water levels that become established by the immediate discharge of excessive water by surface runoff. Outside the topographic depressions, i.e., at the topographic mounds near the fen margins, groundwater only exfiltrates in response to falling water tables by plant transpiration during periods of precipitation deficit (Fig. 3b). During periods of precipitation surplus, however, groundwater levels raise at the topographic mounds, which locally causes the infiltration of local precipitation and its subsequent redistribution from the topographic mounds to the topographic depressions by groundwater flow. As a result of the temporally varying groundwater exfiltration, the relative area of groundwater exfiltration into the poorly drained fen can yield $100 \%$ during dry summer months, and ranges from 40 to $65 \%$ during wet winter months (Fig. 3a and b, Table 2).

Observed ${ }^{3} \mathrm{H}$ concentrations across the poorly drained fen (Fig. 6) confirm the infiltration of ${ }^{3} \mathrm{H}$-rich precipitation at the topographic mounds, and the exfiltration of ${ }^{3} \mathrm{H}$-poor, premodern groundwater at the topographic depressions. The increasing ${ }^{3} \mathrm{H}$ age with increasing depth and from the topographic mounds to the topographic depressions, corresponds to a mixing gradient of brackish palaeo-groundwater and locally infiltrated precipitation. Evidence for this mixing gradient is provided by the permanently high $\mathrm{Cl}$ concentrations $(\mathrm{Cl}>20 \mathrm{mg} / \mathrm{l})$ that increase along the same direction as the ${ }^{3} \mathrm{H}$ age does (Fig. 5). The absence of indicators of locally infiltrated precipitation (ECs $<200 \mu \mathrm{S} / \mathrm{cm}$ and $\mathrm{Cl}$ concentrations $<20 \mathrm{mg} / \mathrm{l}$, see Figs. 4 and 5 respectively) indicates that precipitation mixes with upwelling brackish palaeo-groundwater immediately after infiltration into the fen soil. The observed ECs (Fig. 4) further suggest that brackish palaeo-groundwater disperses through the fen during periods of precipitation deficit to compensate for groundwater losses by plant transpiration, and that brackish palaeogroundwater in the shallow subsurface is diluted by locally infiltrated precipitation during periods of precipitation surplus.

\subsection{Effects of the elimination of drainage ditches}

The numerical experiment indicates that the elimination of drainage ditches from the anthropogenically drained fen causes the reallocation of on-site, permanent groundwater exfiltration zones from the drainage ditches to the topographic depressions as seen in the poorly drained fen (Fig. 3). 

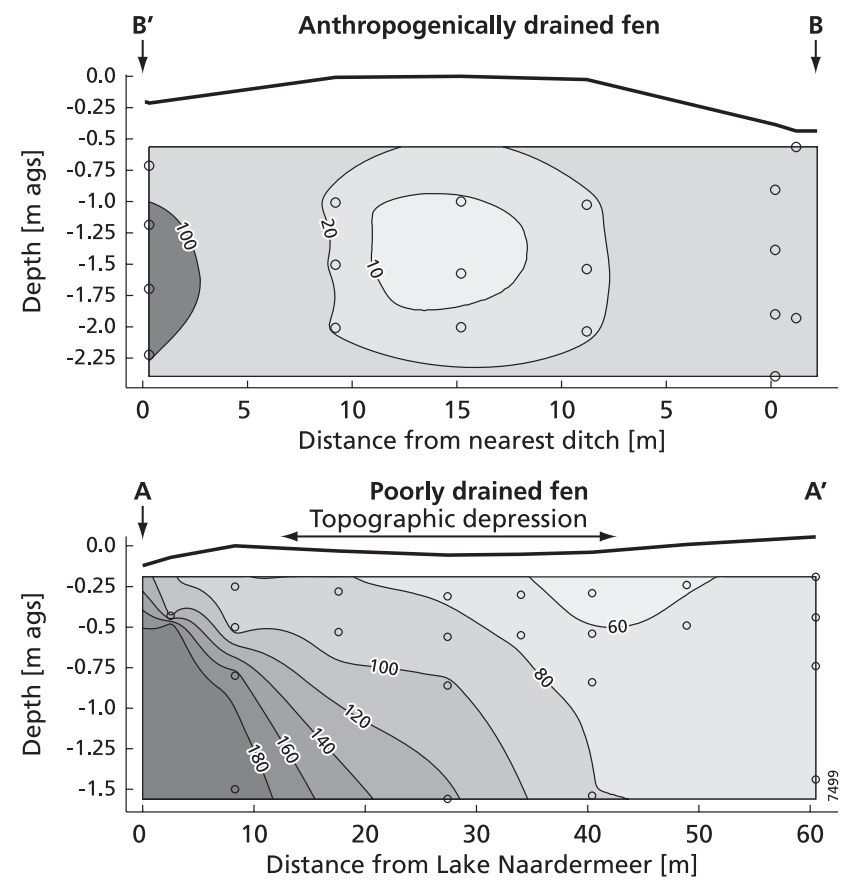

Fig. 5. Time-averaged $\mathrm{Cl}$ concentration $[\mathrm{mg} / \mathrm{l}]$ observed across the anthropogenically drained fen and the poorly drained fen. A- $\mathrm{A}^{\prime}$ and $\mathrm{B}-\mathrm{B}^{\prime}$ signify the positions of the observation transects in Fig. 1. Vertical arrows denote draining elements and horizontal arrow topographic depressions. Cl samples were collected in November 2005, March 2006, May 2006, August 2006, and November 2006. A low $\mathrm{Cl}$ concentration $(\mathrm{Cl}<20 \mathrm{mg} / \mathrm{l}$, see Table 1$)$ indicates the absence of infiltrated surface water in the anthropogenically drained fen. The high $\mathrm{Cl}$ concentrations in the poorly drained fen correspond to a mixing gradient of brackish palaeo-groundwater and locally infiltrated precipitation.

At the topographic mounds, however, groundwater exfiltration remains temporally variable with the precipitation surplus (Fig. 3). Due to the rather irregular surface morphology, i.e., the absence of vast topographic depressions as seen in the poorly drained fen, the relative area of groundwater exfiltration outside the drainage ditches remains small compared to that of the poorly drained fen (Table 2). Nevertheless, the model results indicate the establishment of hydrological conditions similar to those of the poorly drained fen, as exfiltration fluxes outside the drainage ditches increase by several orders of magnitude (Table 2), and surface runoff, instead of drain discharge, becomes the dominant discharge mechanism (Fig. 7). The latter implies that a larger amount of local precipitation discharges from the fen before entering the fen root zone, and that exfiltrated groundwater may disperse across the fen and re-infiltrate at downstream regions.

Although the elimination of drainage ditches from the anthropogenically drained fen only increased the on-site groundwater level with at most a few tens of centimetres, the consequences for regional groundwater flow were rather large. Part of the groundwater that is currently directed to
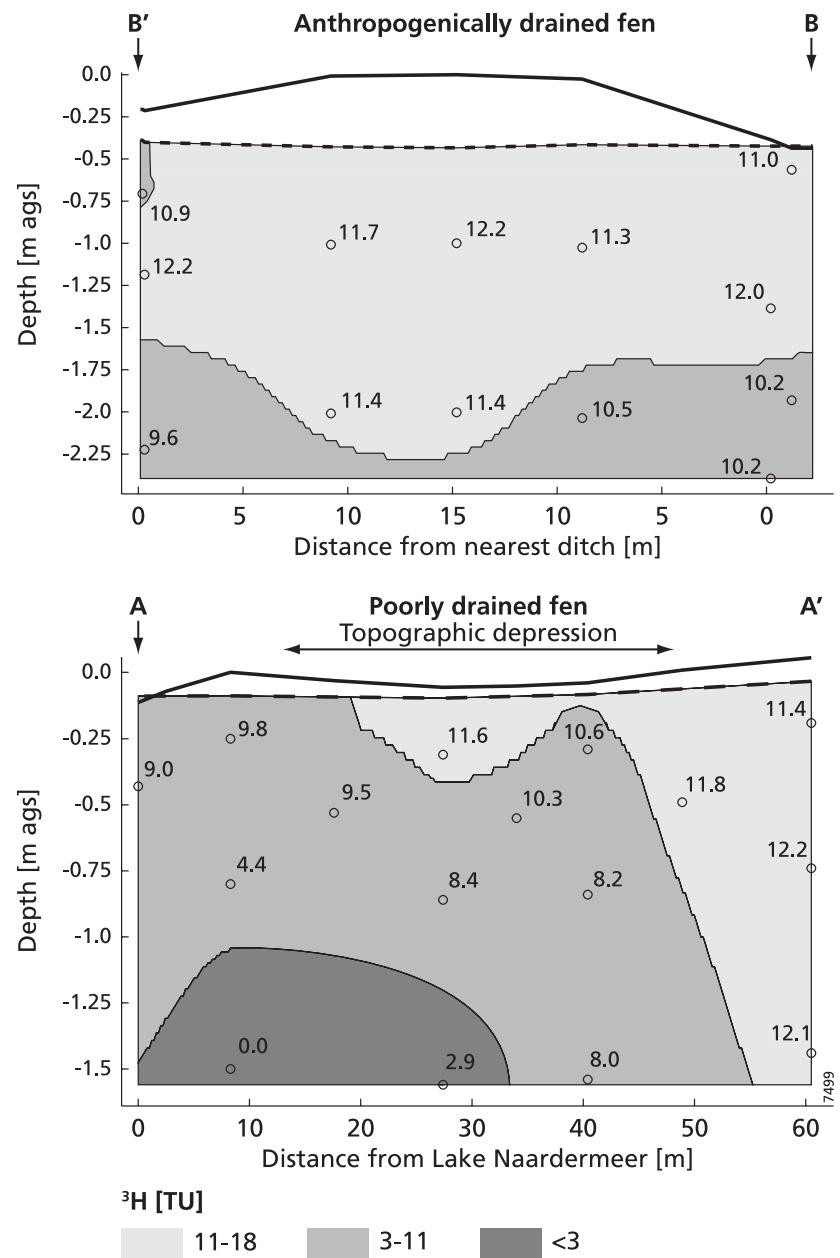

Fig. 6. Tritium concentrations [TU] observed across the anthropogenically drained fen and the poorly drained fen in November 2006. $\mathrm{A}-\mathrm{A}^{\prime}$ and $\mathrm{B}-\mathrm{B}^{\prime}$ signify the positions of the observation transects in Fig. 1. Vertical arrows denote draining elements and horizontal arrows topographic depressions. The ${ }^{3} \mathrm{H}$-isolines correspond to the ${ }^{3} \mathrm{H}$ signatures defined in Fig. 2.

the anthropogenically drained fen was redirected to areas outside the fen, in which the water levels remained permanent. Most of this redirected groundwater exfiltrated into the poorly drained fen, causing an increase in the exfiltration flux (Fig. 7). As a result, the relative area of groundwater exfiltration into the poorly drained fen increased (Fig. 3 and Table 2), as did the groundwater level and discharge flux by surface runoff (Fig. 7). These hydrological changes indicate that the elimination of drainage ditches at the anthropogenically drained fen also enhanced the groundwater supply of the poorly drained fen. 


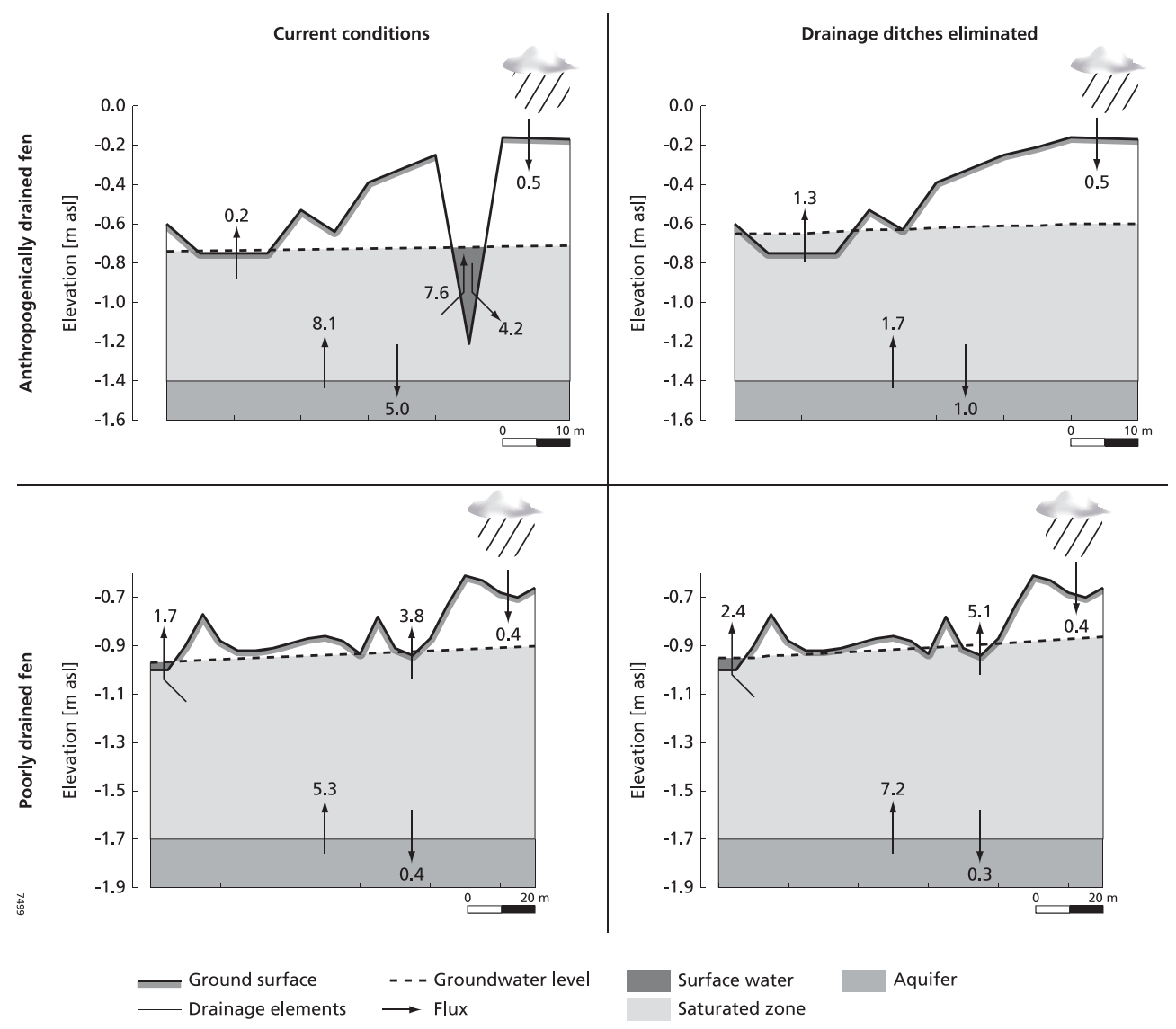

Fig. 7. Effects of elimination of drainage ditches on the water balance $[\mathrm{mm} / \mathrm{d}]$ of the anthropogenically drained fen and the poorly drained fen. Note that part of the groundwater that is currently directed to the anthropogenically drained fen becomes redirected to the poorly drained fen.

\section{Conclusion and discussion}

\subsection{Local impacts on fen deterioration}

The groundwater flow model and the empirical data of chemical and physical properties of groundwater consistently indicated the presence of locally infiltrated precipitation on top of upwelling groundwater across the anthropogenically drained fen, and a mixing gradient of locally infiltrated precipitation and upwelling groundwater across the poorly drained fen. In addition, the numerical experiment showed that the elimination of drainage ditches from the anthropogenically drained fen caused the establishment of hydrological conditions similar to those of the poorly drained fen. These results confirm the hypothesis postulated by, for example, Schot et al. (2004) that anthropogenic drainage does not only cause a lowering of the groundwater table, but also enhances the infiltration of local precipitation across fens. Simultaneously, it prevents upwelling groundwater from entering the fen root zone, as a result of the immediate discharge of exfiltrated groundwater as surface water. These local hydrological consequences of anthropogenic drainage may have far- reaching consequences for the suitability of fen habitat sites, because (1) base ions become leached from fens, instead of supplied to fens, when locally infiltrated precipitation percolates through the fen soil (Almendinger and Leete, 1998), and (2) oxic conditions, instead of anoxic or sub-oxic conditions, become established across the shallow subsurface when the groundwater supply of electron donors has ceased (Boomer and Bedford, 2008a) and aeration of the fen soil is enhanced (De Mars and Wassen, 1999). As the cumulative effects of these shifts in supply rates are thought to contribute to the acidification (Van Diggelen et al., 1996) and eutrophication (Fojt and Harding, 1995; De Mars et al., 1996) of fens, the hydrological consequences of anthropogenic drainage may underlie the loss of fen plant species observed at drained fens in The Netherlands (Grootjans et al., 2005; Van der Hoek and Sykora, 2006) and Sweden (Malson et al., 2008). Moreover, we think that a continuous loss of fen plant species will occur across intensively managed regions like Western Europe during the next decades or centuries as anthropogenically drained fens further deteriorate because of the depletion of the soil chemical buffering capacity caused by the permanent leaching of minerals. 


\subsection{Regional impacts on fen deterioration}

In addition to the above mentioned local hydrological effects of anthropogenic drainage, the results of our study indicate that drainage ditches intercept groundwater that is potentially directed toward downstream regions. This regional hydrological impact of anthropogenic drainage may further reduce the availability of suitable fen habitat sites, as infiltration rates of precipitation will increase at these downstream regions to compensate for the reduced groundwater supply (Van Wirdum, 1991). Although the regional consequences of anthropogenic drainage for the suitability of fen habitat sites may not be as severe as the local consequences, the increased infiltration of precipitation into fens may accelerate plant succession towards species poorer fens or bogs compared to plant succession under more natural conditions (Van Diggelen et al., 1996), especially if large quantities of phosphorous are released from the soil (Kooijman and Paulissen, 2006). For these reasons, anthropogenic drainage may cause fen deterioration on a spatial scale that is larger than one may expect from previous studies that focused only on the local hydrological effects of anthropogenic drainage (Schot et al., 2004; Holden et al., 2004).

\subsection{Hydrological fen restoration}

Knowledge of the hydrological mechanisms behind habitat loss and fragmentation of the remaining fen plant communities in intensively managed regions like The Netherlands is essential to improve currently utilized fen restoration and conservation strategies. These strategies often include measures to restore individual fen reserves e.g. by removing abstraction wells from recharge areas as suggested by, amongst others, Fojt (1994), or by lowering the ground surface of fen reserves by means of top-soil removal as suggested by Van der Hoek and Heijmans (2007). In order to mitigate habitat fragmentation of low-productive fens, however, a spatially coherent hydrological fen restoration strategy is required that is also suitable to restore zones of ceased groundwater supply outside the current fen reserves, as these zones are thought to be less suitable for the establishment of most fen plants (Sjörs and Gunnarsson, 2002), and thus may form barriers against fen plant dispersal. In other words, in order to overcome the dispersal limitations of fen plants in fragmented landscapes (Ozinga et al., 2009), the restoration of spatially contiguous zones of groundwater supply that are common in natural fens (Van Loon et al., 2009b; Succow and Joosten, 2001; Schipper et al., 2007) may be required. Based on knowledge of the hydrology of a near-natural fen in Poland, Van Loon et al. (2009b) have speculated that the elimination of drainage ditches from fens should be given high priority in fen restoration projects in order to re-establish spatially contiguous zones of groundwater supply in fragmented fens. This statement was primarily based on the findings of Schot et al. (2004), who used 2-D groundwater flow and transport models to illustrate that drainage ditches prevent upwelling groundwater from entering fen root zones. The results presented in this paper convincingly demonstrate that the removal of drainage ditches is indeed an effective measure to rewet drained fens with exfiltrating groundwater, even though the on-site exfiltration fluxes may also decrease due to the redirection of groundwater flow to areas outside the drained fen area where the water levels are not altered. This paper further showed that the elimination of drainage ditches from fens may enhance the redistribution of exfiltrated groundwater by surface runoff, which increases the availability and contiguity of potentially suitable fen habitat sites like in natural fens (Van Loon et al., 2009b; Succow and Joosten, 2001). In order to enhance the supply of exfiltrated groundwater to fragmented fens by surface runoff, however, additional measures to reduce the re-infiltration of exfiltrated groundwater may be required. This is because the infiltration conditions across managed fens are thought to prevail on a larger spatial scale than those across natural fens (Wassen et al., 1996; Van Loon et al., 2009a). Potentially suitable measures to reduce infiltration across fens include the inundation of polders and the closing of abstraction wells in fens.

Earlier ecohydrological analyses of the present study area indicated that endangered fen plant communities in the poorly drained fen recently declined in number and size due to succession towards plant communities that are more common in Western Europe (Barendregt et al., 1995; Wassen et al., 1989). This development was mainly attributed to the decreased supply of groundwater originating from the icepushed ridge, which enhanced the infiltration of precipitation and induced the upward movement of brackish palaeogroundwater (Wassen et al., 1989; Schot, 1989) stored below the lake bordering the fen (Schot, 1989). Based on these findings, water management authorities closed the abstraction wells at the ice-pushed ridge in the late 1990s, with the goal of re-establishing the supply of fresh groundwater to the poorly drained fen. Although this measure has certainly increased the amount of fresh groundwater that is available for regional groundwater flow to the fen (Schot, 1989), our empirical data provide evidence that brackish palaeo-groundwater instead of fresh groundwater is still the major source of water for the fen. In other words, the fresh groundwater supply that is required to sustainably conserve the endangered fen plant communities in this area has not become re-established, even though groundwater fluxes from the ice-pushed ridge have increased over the past 10 years. One explanation for this insufficient fresh groundwater supply is that the replacement of brackish palaeo-groundwater by fresh groundwater may be delayed compared to the redirection of groundwater flow. The results of our study indicate, however, that the lack of a fresh groundwater supply may also be due to the interception of groundwater by the drainage ditches that are situated about half a kilometre upstream of the poorly drained fen. This latter explanation would imply that most of the redirected groundwater is 
lost by drain discharge instead of becoming available to fen plants. This renders measures that enhance groundwater flow to fens ineffective when nearby drainage ditches have not been eliminated first. As most fens in Western Europe have been reclaimed by means of the installation of drainage networks (Succow and Joosten, 2001), this is probably a commonly encountered problem that limits the effectiveness of regional hydrological fen restoration measures. For this reason, we suggest that regional measures that enhance groundwater flow to fens be assigned a lower priority than local measures that support the transport of available upwelling groundwater up to the fen surface. For practical reasons, however, it can be more convenient to plan restoration measures in another sequence, but resource managers should then be aware that costly investments to improve the regional hydrology of fen reserves only have effect after measures have been implemented in the direct vicinity of the fens targeted at preventing diffuse loss of groundwater via drainage ditches.

Acknowledgements. The authors thank Michael Stewart and Ab Grootjans for their clear and constructive suggestions to improve the manuscript, and Laura Cobb for proof-reading the manuscript.

Edited by: T. Elliot

\section{References}

Almendinger, J. E. and Leete, J. H.: Peat characteristics and groundwater geochemistry of calcareous fens in the Minnesota River Basin, USA, Biogeochemistry, 43, 17-41, 1998.

Amon, J. P., Thompson, C. A., Carpenter, Q. J., and Miner, J.: Temperate zone fens of the glaciated Midwestern USA, Wetlands, 22, 301-317, 2002.

Barendregt, A., Wassen, M. J., and Schot, P. P.: Hydrological systems beyond a nature reserve, the major problem in wetland conservation of Naardermeer (The Netherlands), Biol. Conserv., 72, 393-405, 1995.

Bedford, B. L., Walbridge, M. R., and Aldous, A.: Patterns in nutrient availability and plant diversity of temperate North American wetlands, Ecology, 80, 2151-2169, 1999.

Boomer, K. M. B. and Bedford, B. L.: Groundwater-induced redox-gradients control soil properties and phosphorus availability across four headwater wetlands, New York, USA, Biogeochemistry, 90, 259-274, 2008a.

Boomer, K. M. B. and Bedford, B. L.: Influence of nested groundwater systems on reduction-oxidation and alkalinity gradients with implications for plant nutrient availability in four New York fens, J. Hydrol., 351, 107-125, 2008b.

Bootsma, M. C., Van den Broek, T., Barendregt, A., and Beltman, B.: Rehabilitation of acidified floating fens by addition of buffered surface water, Restor. Ecol., 10, 112-121, 2002.

Council of Europe: Guidelines for the development of the Pan European Ecological Network, Nature and Environment, Council of Europe Publishing, Strasbourg, 2000.

De Mars, H., Wassen, M. J., and Peeters, W. H. M.: The effect of drainage and management on peat chemistry and nutrient deficiency in the former Jegrznia-floodplain (NE-Poland), Plant Ecol., 126, 59-72, 1996.
De Mars, H. and Wassen, M. J.: Redox potentials in relation to water levels in different mire types in the Netherlands and Poland, Plant Ecol., 140, 41-51, 1999.

Fojt, W. and Harding, M.: Thirty years of change in the vegetation communities of three valley mires in Suffolk, England, J. Appl. Ecol., 32, 561-577, 1995.

Fojt, W. J.: Dehydration and the threat to east anglian fens, England, Biol. Conserv., 69, 163-175, 1994.

Grootjans, A. P., Van Diggelen, R., Wassen, M. J., and Wiersinga, W. A.: The effects of drainage on groundwater quality and plant species distribution in stream valley meadows, Vegetatio, 75, 3748, 1988.

Grootjans, A. P., Hunneman, H., Verkiel, H., and Van Andel, J.: Long-term effects of drainage on species richness of a fen meadow at different spatial scales, Basic Appl. Ecol., 6, 185193, 2005.

Holden, J., Chapman, P. J., and Labadz, J. C.: Artificial drainage of peatlands: hydrological and hydrochemical process and wetland restoration, Prog. Phys. Geog., 28, 95-123, 2004.

Hooftman, D. A. P., van Kleunen, M., and Diemer, M.: Effects of habitat fragmentation on the fitness of two common wetland species, Carex davalliana and Succisa pratensis, Oecologia, 134, 350-359, 2003.

Kemmers, R. H., Van Delft, S. P. J., and Jansen, P. C.: Iron and sulphate as possible key factors in the restoration ecology of rich fens in discharge areas, Wetlands Ecology and Management, 11, 367-381, 2003.

Klijn, F. and Witte, J. M.: Eco-hydrology: groundwater flow and site factors in plant ecology, Hydrogeol. J., 7, 65-77, 1998.

Klimkowska, A., Van Diggelen, R., Bakker, J. P., and Grootjans, A. P.: Wet meadow restoration in Western Europe: A quantitative assessment of the effectiveness of several techniques, Biol. Conserv., 140, 318-328, 2007.

Knetsch, G. J.: Environmental radioactivity in The Netherlands: Results in 2001, Rijksinstituut voor Volksgezondheid en Milieu (National Institute for Public Health and Environment), Bilthoven, The Netherlands, 610056048/2002, 2002.

Knetsch, G. J.: Environmental radioactivity in The Netherlands: Results in 2006, Rijksinstituut voor Volksgezondheid en Milieu (National Institute for Public Health and Environment), Bilthoven, The Netherlands, 610791001/2007, 2007.

Kooijman, A. M. and Paulissen, M. P. C. P.: Higher acidification rates in fens with phosphorous enrichment, Appl. Veg. Sci., 9, 205-212, 2006.

Lamers, L. P. M., Smolders, A. J. P., and Roelofs, J. G. M.: The restoration of fens in the Netherlands, Hydrobiologica, 478, 107130, 2002.

Lamers, L. P. M., Tomassen, H. B. M., and Roelofs, J. G. M.: Sulfate-induced eutrophication and phytotoxicity in freshwater wetlands, Environ. Sci. Technol., 32, 199-205, 1998.

Malson, K., Backeus, I., and Rydin, H.: Long-term effects of drainage and initial effects of hydrological restoration on rich fen vegetation, Appl. Veg. Sci., 11, 99-106, 2008.

McDonald, M. G. and Harbaugh, A. W.: A modular threedimensional finite-difference groundwater flow model, Techniques of water-resources investigations of the United States Geological Survey, United States Government Printing Office, Washington, USA, 1988.

Mehl, S., Hill, M. C., and Leake, S. A.: Comparison of local grid 
refinement methods for Modflow, Ground Water, 44, 792-796, 2006.

Meinardi, C. R.: Groundwater recharge and travel times in the sandy regions of The Netherlands, Ph.D. Thesis, Free University, Amsterdam, The Netherlands, 211 pp., 1994.

Ozinga, W. A., Romermann, C., Bekker, R. M., Prinzing, A., Tamis, W. L. M., Schaminee, J. H. J., Hennekens, S. M., Thompson, K., Poschlod, P., Kleyer, M., Bakker, J. P., and Van Groenendael, J. M.: Dispersal failure contributes to plant losses in NW Europe, Ecol. Lett., 12, 66-74, 2009.

Post, V. E. A., Van der Plicht, H., and Meijer, H. A. J.: The origin of brackish and saline groundwater in the coastal area of The Netherlands, Neth. J. Geosci., 82, 133-147, 2003.

RIVM: Chemical composition of precipitation over the Netherlands. Validated data 1992-2004, Rijksinstituut voor volksgezondheid en milieu (National Institute for Public Health and the Environment), Bilthoven, The Netherlands, online available at: (http://www.lml.rivm.nl/data_val/data/lmre_1992-2004.xls), 2005.

Robertson, W. D. and Cherry, J. A.: Tritium as an indicator of recharge and dispersion in a groundwater system in central Ontario, Water Resour. Res., 25, 1097-1109, 1989.

Schipper, A. M., Zeefat, R., Tanneberger, F., van Zuidam, J. P., Hahne, W., Schep, S. A., Loos, S., Bleuten, W., Joosten, H., Lapshina, E. D., and Wassen, M. J.: Vegetation characteristics and eco-hydrological processes in a pristine mire in the Ob River valley (Western Siberia), Plant Ecol., 193, 131-145, 2007.

Schot, P. P., Barendregt, A., and Wassen, M. J.: Hydrology of the wetland Naardermeer: influence of the surrounding area and impact on vegetation, Agr. Water Manage., 14, 459-470, 1988.

Schot, P. P.: Groundwater systems analysis of the Naardermeer wetland, The Netherlands, in: IAH Selected papers on Hydrology, 28th International Geological Congress, Washington, USA, 1, 257-269, 1989.

Schot, P. P. and Wassen, M. J.: Calcium concentrations in wetland groundwater in relation to water sources and soil conditions in the recharge area, J. Hydrol., 141, 197-217, 1993.

Schot, P. P., Dekker, S. C., and Poot, A.: The dynamic form of rainwater lenses in drained fens, J. Hydrol., 293, 74-84, 2004.
Sjörs, H. and Gunnarsson, U.: Calcium and $\mathrm{pH}$ in North and Central Swedish mire waters, J. Ecol., 90, 650-657, 2002.

Succow, M. and Joosten, H.: Landschaftsokologische Moorkunde, Schweizerbart, Stuttgart, Germany, 2001.

Van der Hoek, D. and Sykora, K. V.: Fen-meadow succession in relation to spatial and temporal differences in hydrological and soil conditions, Appl. Veg. Sci., 9, 185-194, 2006.

Van der Hoek, D. and Heijmans, M. M. P. D.: Effectiveness of turf stripping as a measure for restoring species-rich fen meadows in suboptimal hydrological conditions, Restor. Ecol., 15, 627-637, 2007.

Van Diggelen, R., Molenaar, W. J., and Kooijman, A. M.: Vegetation succession in a floating mire in relation to management and hydrology, J. Veg. Sci., 7, 809-820, 1996.

Van Heerd, R. M., Kuijlaars, E. A. C., Teeuw, M. P., and Van 't Zand, R. J.: Productspecificatie AHN 2000, Rijkswaterstaat, Delft, MDTGM2000.13, 2000.

Van Loon, A. H., Schot, P. P., Griffioen, J., Bierkens, M. F. P., and Wassen, M. J.: Palaeo-hydrological reconstruction of a managed fen area in The Netherlands, J. Hydrol, in press, 2009a.

Van Loon, A. H., Schot, P. P., Griffioen, J., Bierkens, M. F. P., Batelaan, O., and Wassen, M. J.: Throughflow as a determining factor for habitat contiguity in a near-natural fen, J. Hydrol, in press, 2009b.

Van Wirdum, G.: Vegetation and hydrology of floating rich fens, Ph.D. Thesis, University of Amsterdam, Amsterdam, The Netherlands, 310 pp., 1991.

Wassen, M. J., Barendregt, A., Bootsma, M. C., and Schot, P. P.: Groundwater chemistry and vegetation of gradients from rich fen to poor fen in the Naardermeer, The Netherlands, Vegetatio, 79, 117-132, 1989.

Wassen, M. J., Barendregt, A., Schot, P. P., and Beltman, B.: Dependency of local mesotrophic fens on a regional groundwater flow system in a poldered river plain in the Netherlands, Landscape Ecol., 5, 21-38, 1990.

Wassen, M. J., van Diggelen, R., Wolejko, L., and Verhoeven, J. T. A.: A comparison of fens in natural and artificial landscapes, Vegetatio, 126, 5-26, 1996. 